\title{
Structure of New Monoterpene Glycoside from Sibiraea angustata RCHD. and Its Anti-obestic Effect
}

\author{
Yoshiaki Ito, ${ }^{*, a}$ Satoshi Kamo, ${ }^{a}$ Samir Kumar SAdHu, ${ }^{b}$ Takashi OHTsuki,${ }^{b}$ Masami Ishibashi, ${ }^{b}$ and \\ Yoshihiro KANO ${ }^{c}$ \\ ${ }^{a}$ Iskra Industry Co., Ltd.; 1-14-2 Nihonbashi, Chuo-ku, Tokyo 103-0027, Japan: ${ }^{b}$ Graduate School of Pharmaceutical \\ Sciences, Chiba University; 1-33 Yayoi-cho, Inage-ku, Chiba 263-8522, Japan: and ${ }^{c}$ Institute of Natural Medicine, \\ University of Toyama; 2630 Sugitani, Toyama 930-0194, Japan. \\ Received October 8, 2008; accepted December 19, 2008; published online January 8, 2009
}

\begin{abstract}
A new monoterpene glycoside (1) isolated from the aerial part of Sibirae angustata RchD. (Rosaceae) was found to be 1-O- $\beta$-D-glucopyranosyl-geraniol-5,10-olide and named as sibiskoside. Acute toxicity study revealed that oral administration of $1(2.5 \mathrm{~g} / \mathrm{kg}$ body weight $)$ to mice resulted in no death and no evidence of abnormalities in internal organs. Its oral administration to the mice reared with high-fat diet resulted in weight-loss, which was also reflected in serum triglyceride and sugar level, and the weight of abdominal fat. Sibiskoside could be considered to be an active ingredient of Liucha for exerting weight-loss effect in a drink of $S$. angustata.
\end{abstract}

Key words Sibiraea angustata; sibiskoside; monoterpene; serum triglyceride level; obesity-prevention

Sibiraea angustata RCHD. (Rosaceae) is a shrub found at high-elevation dryland around 3000 to $4000 \mathrm{~m}$ height in the areas of Xizang (Tibet), Sichuan, Qinghai, Gansu and Yunnan in China. The Tibetans believe that a long-term consumption of the aerial part of $S$. angustata as tea has some benefit of health in humans. And they avoid mixing this plant into sheep feed, since it has been practically known to cause weight-loss during ingestion. It was no more than one of folklores before our study. These traditions were not recorded on any literature, but directly collected by our hearing from Tibetans. This folklore leads to the hypothesis that the aerial part of $S$. angustata might have preventive effects on obesity. Then, we had interest and study about the properties of $S$. angustata.

In the previous studies, 43 essential oils ${ }^{1)}$ and glucityl ferulate (sibirate) $)^{2)}$ were identified from the aerial part of $S$. angustata. The extract of $S$. angustata improved immune system ${ }^{3)}$ and prevented $\mathrm{CCl}_{4}$-induced liver diseases. ${ }^{4)}$ However, the active ingredients for these pharmacological effects have not yet been identified.

In this study, we present the isolation and structure determination of a new compound (1), together with two known compounds, isoferulic acid and quercetin 3-O- $\alpha$-L-arabinopyranosyl( $1-6)$ - $\beta$-D-galactopyranoside ${ }^{5)}$ from the aerial part of $S$. angustata, and the anti-obestic effect of $\mathbf{1}$ is also discussed.

\section{Results and Discussions}

The aerial part of $S$. angustata was boiled in water and the decoction was spray dried. The powdered extract was extracted with EtOH under reflux, and EtOH soluble part was then concentrated under reduced pressure to give a brown solid material. It was applied upon a charcoal column and eluted with stepwise gradients of $\mathrm{H}_{2} \mathrm{O}-\mathrm{EtOH}$. From the $20 \%$ EtOH fraction, compound 1 was obtained as colorless amorphous powder by preparative HPLC. It was established to have a molecular formula of $\mathrm{C}_{16} \mathrm{H}_{24} \mathrm{O}_{8}$ by high resolutionpositive FAB-MS spectrum. Its IR spectrum showed absorption maxima exhibiting a lactone carbonyl $\left(1745 \mathrm{~cm}^{-1}\right)$ and hydroxyl group $\left(3354 \mathrm{~cm}^{-1}\right)$. UV spectrum exhibited an ab- sorption maximum at $220 \mathrm{~nm}(\varepsilon=13000)$. The ${ }^{1} \mathrm{H}-\mathrm{NMR}$ spectrum indicated the presence of two tertiary methyl groups $\left[\delta_{\mathrm{H}} 1.61,1.63\right.$, (each $\left.\left.3 \mathrm{H}, \mathrm{s}\right)\right]$ and an anomeric proton $\left[\delta_{\mathrm{H}} 4.97(1 \mathrm{H}, \mathrm{d}, J=7.9 \mathrm{~Hz})\right]$. The ${ }^{13} \mathrm{C}-\mathrm{NMR}$ and DEPT spectra suggested the presence of two tertiary methyl groups, three methylenes, seven methines, three quaternary carbons including a carbonyl group. In addition, heteronuclear single quantum correlation (HSQC) analysis suggested the presence of a methine $\left(\delta_{\mathrm{C}} 124.1\right)$ overlapped with a signal due to the solvent (pyridine) (Table 1).

The chemical structure of the compound $\mathbf{1}$ was elucidated by ${ }^{1} \mathrm{H}-{ }^{1} \mathrm{H}$ correlation spectroscoopy (COSY), nuclear overhauser effect spectroscopy (NOESY), HSQC and heteronuclear multiple bond correlation (HMBC) analyses (Fig. 1). The connectives of these partial structures and the functional groups were determined by analysis of HMBC. As shown in Fig. 1, key long range correlations were observed between the following proton and carbon signals: $\mathrm{H}-1$ and $\mathrm{C}-2, \mathrm{C}-3$; $\mathrm{H}-2$ and $\mathrm{C}-4, \mathrm{C}-10 ; \mathrm{H}-4(\alpha$ and $\beta$ ) and $\mathrm{C}-3, \mathrm{C}-6$; H-6 and C7, C-8, C-9; H-8 and C-6, C-7, C-9; H-9 and C-6, C-7, C-8; $\mathrm{H}-1^{\prime}$ and $\mathrm{C}-1$. Furthermore, NOESY spectrum exhibited

Table 1. ${ }^{1} \mathrm{H}$ - and ${ }^{13} \mathrm{C}-\mathrm{NMR}$ Spectrum Data for $\mathbf{1}$ in Pyridine- $d_{5}$

\begin{tabular}{cclr}
\hline \hline & Position & \multicolumn{1}{c}{$\delta_{\mathrm{H}}$} & $\delta_{\mathrm{C}}$ \\
\hline \multirow{2}{*}{ Aglycone } & 1 & $5.30(2 \mathrm{H}, \mathrm{m})$ & 66.3 \\
& 2 & $6.56(1 \mathrm{H}, \mathrm{m})$ & 139.7 \\
& 3 & & 126.6 \\
& 4 & $2.50,2.95(\mathrm{each}, 1 \mathrm{H}, \mathrm{m})$ & 35.7 \\
& 5 & $5.21(1 \mathrm{H}, \mathrm{m})$ & 75.1 \\
& 6 & $5.21(1 \mathrm{H}, \mathrm{m})$ & 124.1 \\
& 7 & & 139.7 \\
Glc & & $1.63(3 \mathrm{H}, \mathrm{s})$ & 25.5 \\
& 9 & & 18.2 \\
& 10 & $4.97(1 \mathrm{H}, \mathrm{d}, J=8.0 \mathrm{~Hz})$ & 169.9 \\
& $1^{\prime}$ & $4.11(1 \mathrm{H}, \mathrm{t}, J=8.0 \mathrm{~Hz})$ & 104.5 \\
$2^{\prime}$ & $4.28(1 \mathrm{H}, \mathrm{m})$ & 75.0 \\
$3^{\prime}$ & $4.28(1 \mathrm{H}, \mathrm{m})$ & 78.3 \\
$4^{\prime}$ & $3.95(1 \mathrm{H}, \mathrm{m})$ & 71.4 \\
$5^{\prime}$ & $4.36,4.52(\mathrm{each}, 1 \mathrm{H}, \mathrm{m})$ & 62.4 \\
& $6^{\prime}$ & &
\end{tabular}


cross-peaks between $\mathrm{H}-2$ signal and both of signals due to $\mathrm{H}$ $4(\alpha$ and $\beta)$. The carbonyl group at $\mathrm{C}-10\left(\delta_{\mathrm{C}} 169.9\right)$ was inferred to be connected with an oxymethine carbon $\left(\mathrm{C}-5, \delta_{\mathrm{C}}\right.$ 75.1) through a lactone-linkage since the oxymethine proton (H-5) resonated at significantly low field $\left(\delta_{\mathrm{H}} 5.21\right)$. Moreover, on acid hydrolysis, 1 afforded D-glucose which was identified by TLC and $[\alpha]_{D}$. In order to determine the absolute stereochemistry, 1 was converted into di-MTPA esters through 4-steps reactions (Chart 1). By applying KusumiMosher method $^{6)}$ for these MTPA esters $(\mathbf{8 a}, \mathbf{b})$, the absolute configuration of $\mathrm{C}-5$ of 1 was suggested as $R$ as shown in Fig. 1 . Thus, the structure of 1 was determined as $1-O-\beta$-Dglucopyranosyl-geraniol-5,10-olide.

Acute toxicity experiments revealed that 1 was extremely low toxic. The oral $\mathrm{LD}_{50}$ value for mice was more than $2500 \mathrm{mg} / \mathrm{kg}$. In both sexes, there were no difference in general condition, body weight and food intakes in all groups (data not shown). No deaths were observed in all groups.

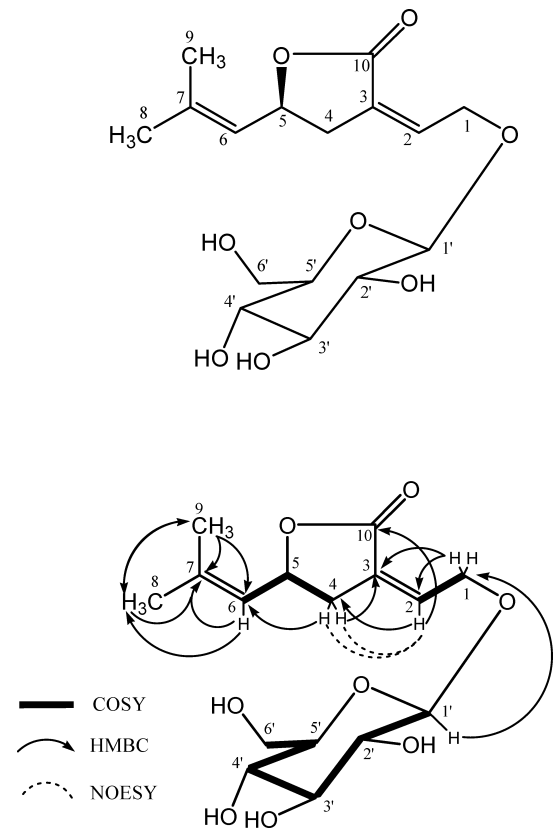

Fig. 1. Chemical Structure of 1
The experiment of evaluation of $\mathbf{1}$ for the effect on the body weight of mice reared with high-fat diet was conducted. Before mice were feeded with high-fat diet, there were no significant differences of body weight among the 2 experimental groups. Then, the mice were reared with high-fat diet with or without 1 as drinking water for $42 \mathrm{~d}$. The intakes of the feed and water were not significantly different between control and the group treated with 1 (Fig. 2). In the preliminary study, the body weight of control group reared with high-fat diet was confirmed to be increased compared with normal mice fed with usual diet (data not shown). The weight of mice treated with $\mathbf{1}$ was significantly lower than the control group from day 21 to 42 (Fig. 3), suggesting that 1

(A)

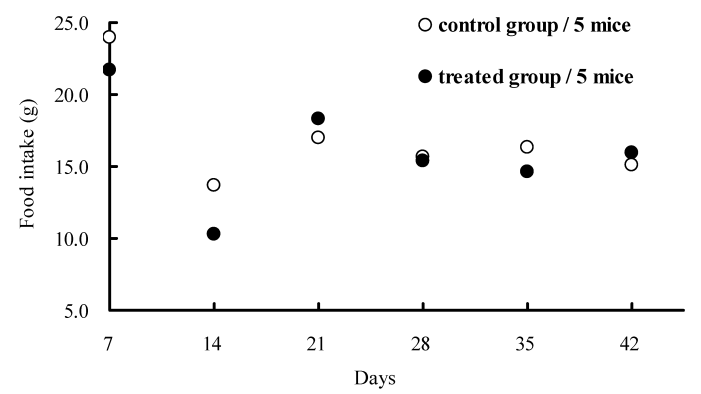

(B)

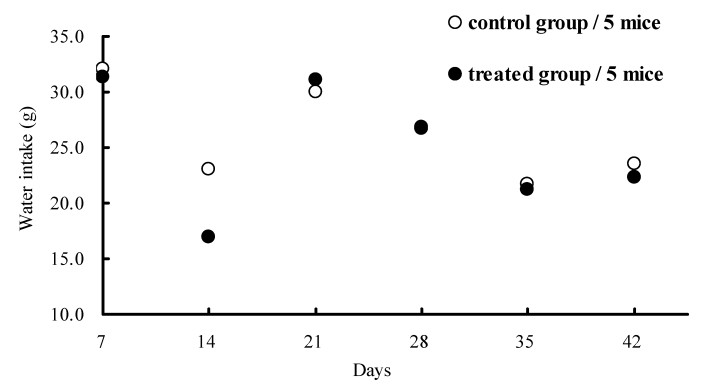

Fig. 2. Profiles of Food (A) and Water (B) Intake in the Mice Rared with High-Fat Diet with or without 1

Open circle, control group; closed circle, 1-treated group. Data were $1 \mathrm{~d}$ food intake of 5 mice.
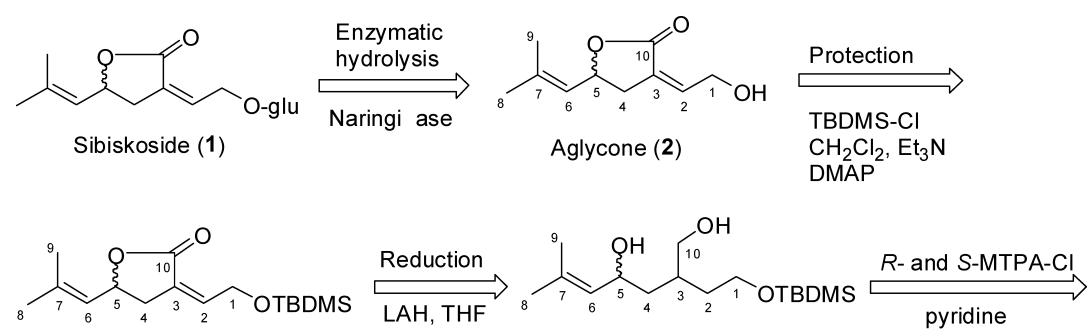

(5)

(7)

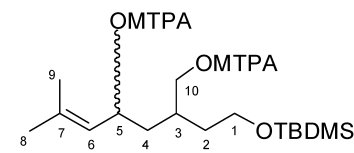

(8)

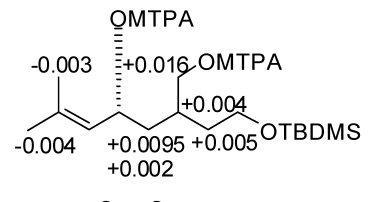

$\Delta \delta(\delta S-\delta R)$ values

8a (S)-MTPA ester 8b (R)-MTPA ester 


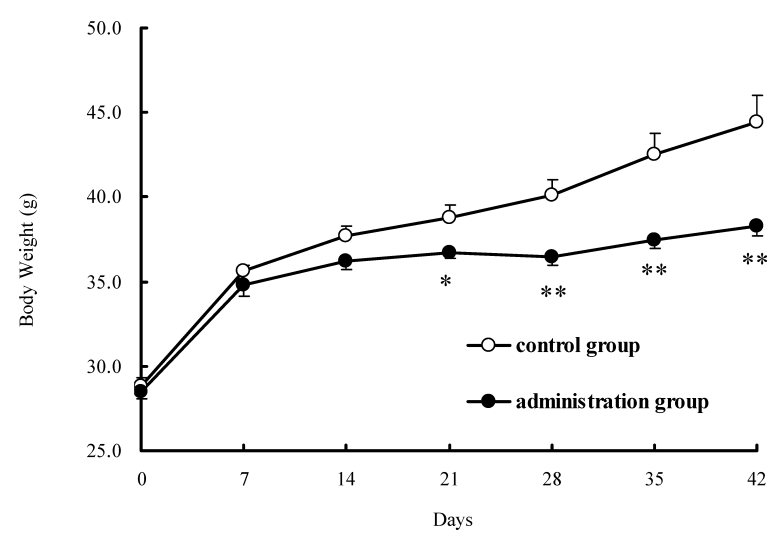

Fig. 3. Profiles of Body Weight of the Mice Treated with Compound 1

Open circle, control group; closed circle, compound 1-treated group. Data were expressed as mean \pm S.E. $* p<0.05, * * p<0.01 v$ s. control group.

Table 2. Effect of Compound $\mathbf{1}$ on Blood Biochemical Values

\begin{tabular}{lccc}
\hline \hline \multirow{2}{*}{ Group } & \multicolumn{2}{c}{ Blood biochemical values (mg/dl) } \\
\cline { 2 - 4 } & $\begin{array}{c}\text { Total } \\
\text { cholesterol }\end{array}$ & Triglyceride & $\begin{array}{c}\text { Blood glucose } \\
\text { level }\end{array}$ \\
\hline Control & $161 \pm 30$ & $94 \pm 22$ & $228 \pm 20$ \\
Compound 1 & $118 \pm 22^{*}$ & $26 \pm 16^{* *}$ & $183 \pm 36^{*}$ \\
\hline
\end{tabular}

Data were expressed as mean \pm S.E. of five mice. $* p<0.05$ and $* * p<0.01 v s$. control group.

has suppressive effect on the increase of body weight. At day 42 , mice were sacrificed and the blood was corrected and the weights of fat around the kidney, the posterior abdominal wall and the epididymis were measured. As shown in Table 2, total cholesterol (TC), triglyceride (TG) and blood glucose (BG) levels were significantly lower than those of control group. Weights of liver, fat around the kidney and the posterior abdominal wall were slightly lower than the control without statistically significant difference. However, the weight of fat around the epididymis was significantly lower than that in control (Table 3). That is, it was suggested that $\mathbf{1}$ would have the effect of lowering body fat, particularly, viscous fat, or would have suppressive effect on the accumulation of fat. It is expected that $\mathbf{1}$ had an action of ameliorating obesity. Although we are unable to clearly describe the mechanism behind the ameliorating obesity effect of $\mathbf{1}$, the administration of $\mathbf{1}$ did significantly affect the plasma levels of TC, TG, and BG. It is speculated that compound $\mathbf{1}$ might suppress the increase in body weight in the mice reared with high-fat diet by the inhibition of TG absorption.

Lipids are known to be an important energy source, but excess intake may induce obesity and hyperlipidemia. Obesity is an independent risk factor for cardiac disease ${ }^{7)}$ which has been associated conditions such as hypertension and diabetes. For example, as with other heart failure risk factors, obesity frequently leads to left ventricular hypertrophy, ${ }^{8-11)}$ and because of its epidemic nature in developed societies, obesity is a very important public health problem. ${ }^{12,13)}$ Keeping the body weight level within the normal range is important for the prevention of variety diseases such as arteriosclerosis, cerebral apoplexy and myocardial infarction etc. So far, $S$. angustata has been known as the plant with beneficial ef-
Table 3. Effect of Compound $\mathbf{1}$ on Weight of Liver and Intra-abdominal Fat

\begin{tabular}{lcccc}
\hline \hline \multirow{2}{*}{ Group } & $\begin{array}{c}\text { Weight of } \\
\text { liver }(\mathrm{g})\end{array}$ & Kidney & $\begin{array}{c}\text { Posterior } \\
\text { abdominal wall }\end{array}$ & Epididymis \\
\cline { 3 - 5 } & & & & \\
\hline Control & $1.40 \pm 0.22$ & $0.116 \pm 0.113$ & $0.291 \pm 0.120$ & $1.540 \pm 0.559$ \\
Compound 1 & $1.12 \pm 0.12$ & $0.035 \pm 0.010$ & $0.186 \pm 0.096$ & $0.445 \pm 0.215^{* *}$ \\
\hline Data are expressed as mean \pm S.E. of five mice. $* * p<0.01$ vs. control group.
\end{tabular}

fects on health, however, the effect of $\mathbf{1}$ has never been reported. In this study, the possibility was suggested by new molecular entity "compound 1" discovered from S. angustata as a preventive medicine of the obesity syndrome. We are currently running an additional study to evaluate the mechanism of compound $\mathbf{1}$.

\section{Experimental}

General ${ }^{1} \mathrm{H}$ - and ${ }^{13} \mathrm{C}$-NMR spectra were measured on Varian unity Inova-500 $\left({ }^{1} \mathrm{H}, 500 \mathrm{MHz} ;{ }^{13} \mathrm{C}, 125 \mathrm{MHz}\right.$, Varian Co., CA, U.S.A.) spectrometers. Chemical shift values are given in ppm using TMS as an internal standard. MS spectra were obtained using a JOEL JMS-HX110A mass spectrometer (JEOL Ltd., Tokyo). Optical rotations were measured on a JASCO P-1020 polarimeter (JASCO Ltd., Tokyo). IR spectra were measured on a JASCO FT-IR 230 spectrometer.

Plant Material The plant material of $S$. angustata cultivated in the field of Apa in Sichuan province of China in 2002 was used in this study. This plant was identified by professor Wang Tian Zhi in West China School of Pharmacy, Sichuan University.

Extraction and Isolation One hundred kilograms of the aerial part of $S$. angustata was extracted twice with boiling water of $10001 \mathrm{for} 1 \mathrm{~h}$, and the decoction was pulverized by spray dry method, yielding $33.7 \mathrm{~kg}$ of the extract. The powdered extract $(3.0 \mathrm{~kg})$ was eluted with $\mathrm{EtOH}(31 \times 3)$ under reflux, and the EtOH eluate was concentrated under reduced pressure to give a brown solid material $(1.3 \mathrm{~kg})$. One kilogram of this material was applied upon a charcoal (Charcoal Activated, Wako, Osaka) column chromatography, and eluted successively with stepwise gradients of $\mathrm{H}_{2} \mathrm{O}-\mathrm{EtOH}(20 \%$, $40 \%, 60 \%, 90 \%, 100 \% \mathrm{EtOH})$. The $20 \% \mathrm{EtOH}$ fraction was concentrated under reduced pressure to give a brown solid material $(98 \mathrm{~g})$. Seventy-two grams of the fraction was applied upon a silica-gel (Silicagel $60 \mathrm{~N}$, Merck Japan, Tokyo) column chromatography, and eluted with EtOAc to give fractions (Fr. A-1-A-4). Fr. A-3 (15 g) was purified by preparative HPLC (column, Cosmosil 5C18-AR-II, $20 \phi \times 250 \mathrm{~mm}$, Nacalai, Kyoto; mobile phase, $25 \% \mathrm{MeOH}, 8 \mathrm{ml} / \mathrm{min})$ to give compound $1(1.2 \mathrm{~g})$ at the retention time, 54 min. Furthermore, compound 2 (2.5 g) was obtained from $90 \% \mathrm{EtOH}$ fraction of charcoal column chromatography by repeated recrystallization and identified as isoferulic acid by comparison of spectral data with those of authentic sample (Tokyo Chemical Industry Co., Tokyo).

On the other hand, the EtOH eluate $(1.4 \mathrm{~kg})$ was applied upon a Diaion HP-20 resin (Mitsubishi Chemical Co., Tokyo) column chromatography, and eluted successively with stepwise gradients of $\mathrm{H}_{2} \mathrm{O}-\mathrm{MeOH}(20 \%, 50 \%$, $80 \%, 100 \% \mathrm{MeOH})$ and acetone. The $50 \% \mathrm{MeOH}$ fraction was concentrated under reduced pressure to give a brown solid material (220 g). Fifty grams of the material was applied upon a silica-gel column and eluted successively with $\mathrm{CHCl}_{3}: \mathrm{MeOH}: \mathrm{H}_{2} \mathrm{O}=9: 1: 0.1,8: 2: 0.1,7: 3: 0.2,7: 3: 0.5,6: 4: 1$, $5: 5: 1$, and $\mathrm{MeOH}$ to give fractions (Fr. B-1-B-9). Compound 3 was obtained from Fr. B-7 by recrystallization, and identified as quercetin 3-O- $\alpha$-Larabinopyranosyl $(1 \rightarrow 6)-\beta$-D-galactopyranoside $(190 \mathrm{mg})$ by comparison of spectral data.

1-O- $\beta$-D-Glucopyranosyl-geraniol-5,10-olide (1) Colorless amorphous powder. $[\alpha]_{\mathrm{D}}^{22}-20^{\circ}(c=1.0, \mathrm{MeOH}) ;{ }^{1} \mathrm{H}$ - and ${ }^{13} \mathrm{C}-\mathrm{NMR}$ spectra: see Table 1; HR-positive FAB-MS, $m / z$ : $367.1369[\mathrm{M}+\mathrm{Na}]^{+}\left(\mathrm{Calcd}\right.$ for $\mathrm{C}_{16} \mathrm{H}_{25} \mathrm{O}_{8} \mathrm{Na}$; 367.1368); UV (MeOH): $\lambda_{\max } 220(\varepsilon=13000)$; IR $\left(\mathrm{NaCl}, \mathrm{cm}^{-1}\right): 3354$ $(\mathrm{OH}), 1745(\mathrm{C}=\mathrm{O})$.

Acid Hydrolysis of 1 Compound $1(50 \mathrm{mg})$ was heated in $1 \mathrm{~N} \mathrm{HCl}$ $(3 \mathrm{ml})$ at $80^{\circ} \mathrm{C}$ for $5 \mathrm{~h}$ and neutralized by passing through an ion-exchange resin (Amberlite IRA410J, $\mathrm{OH}^{-}$form, Organo Co., Tokyo) column. The reaction mixtures were applied upon Wakogel 100C18 (Wako Pure Chemical Industries, Osaka) column and eluted with $\mathrm{H}_{2} \mathrm{O}$ to give sugar fraction. 
The monosaccharide were identified as D-glucose by $[\alpha]_{\mathrm{D}}^{21}+66.9^{\circ}(c=$ $0.48, \mathrm{H}_{2} \mathrm{O}$ ) and TLC using Silica gel 60 (Merck Japan, Tokyo) with EtOAc : $\mathrm{AcOH}: \mathrm{MeOH}: \mathrm{H}_{2} \mathrm{O}=12: 3: 3: 2$ to give $R f$ value 0.6 , which is fitted to standard D-glucose.

Preparation of MTPA Esters from 1 Compound 1 (140 mg) was subjected to enzyme hydrolysis by treatment with naringinase $(700 \mathrm{mg})$ in acetone buffer $(50 \mathrm{~mm}, \mathrm{pH} 5.5$; acetic acid $45.3 \mathrm{mg}$, anhydrous sodium acetate $348 \mathrm{mg}$ and $\mathrm{H}_{2} \mathrm{O}$ up to $100 \mathrm{ml}$ ) at $37^{\circ} \mathrm{C}$ for $16 \mathrm{~h}$. The aqueous solution was extracted with EtOAc $(50 \mathrm{ml} \times 3)$ followed by HPLC purification (YMCPack ODS-AM, $10 \times 250 \mathrm{~mm}$; flow rate, $2 \mathrm{ml} / \mathrm{min}$; RI detection) to give aglycone $(29.5 \mathrm{mg})$. The aglycone $(20 \mathrm{mg})$ was treated with trimethyldimethylsilyl chloride $(20 \mathrm{mg})$ in the presence of triethylamine $(24 \mu \mathrm{l})$ and 4-dimethylaminopyridine $(2 \mathrm{mg})$ in $\mathrm{CH}_{2} \mathrm{Cl}_{2}(0.7 \mathrm{ml})$ at room temperature for $18 \mathrm{~h}$ under argon atmosphere. The reaction mixture was evaporated and purified with a silica gel column chromatography with hexane/acetone $(3: 1)$ to give a TBDMS ether $(6.2 \mathrm{mg})$, which was then reduced with $\mathrm{LiAlH}_{4}(4 \mathrm{mg})$ in $\mathrm{THF}(0.4 \mathrm{ml})$ at room temperature for $10 \mathrm{~min}$. After addition of $1 \mathrm{~N} \mathrm{HCl}$, extraction with EtOAc and evaporation of the organic layer afforded diol $(2.1 \mathrm{mg})$. A part of the diol $(0.5 \mathrm{mg})$ was treated with $(R)$-MTPACl $(5 \mu \mathrm{l})$ in pyridine $(100 \mu \mathrm{l})$ at room temperature for $24 \mathrm{~h}$. After addition of $\mathrm{H}_{2} \mathrm{O}$, extraction with EtOAc followed by purification with silica gel column chromatography with $\mathrm{CHCl}_{3}$ /acetone $(9: 1)$ afforded the $(S)$-MTPA ester (8a) $(0.4 \mathrm{mg}) .{ }^{1} \mathrm{H}-\mathrm{NMR}\left(\mathrm{CDCl}_{3}\right) \delta 4.08$ and 4.20 (each $\left.1 \mathrm{H}, \mathrm{m}, \mathrm{H}_{2}-1\right), 0.86$ and 1.28 (each $\left.1 \mathrm{H}, \mathrm{m}, \mathrm{H}_{2}-2\right), 1.51(1 \mathrm{H}, \mathrm{m}, \mathrm{H}-3), 1.09$ and 1.54 (each $1 \mathrm{H}, \mathrm{m}, \mathrm{H}_{2}-$ 4), $3.99(1 \mathrm{H}, \mathrm{m}, \mathrm{H}-5), 5.10(1 \mathrm{H}, \mathrm{m}, \mathrm{H}-6), 1.64\left(3 \mathrm{H}, \mathrm{m}, \mathrm{H}_{3}-9\right), 3.51$ and 4.03 (each $\left.1 \mathrm{H}, \mathrm{m}, \mathrm{H}_{2}-10\right), 1.23\left(9 \mathrm{H}, \mathrm{s}, t-\mathrm{Bu}\right.$ and $0.048\left(6 \mathrm{H}, \mathrm{s}, \mathrm{CH}_{3} \times 2\right)$. Treatment of the diol $(0.5 \mathrm{mg})$ with $(S)$-MTPACl by the same procedures afforded the $(R)$-MTPA ester $(\mathbf{8 b})(0.4 \mathrm{mg}) .{ }^{1} \mathrm{H}-\mathrm{NMR}\left(\mathrm{CDCl}_{3}\right) \delta 4.08$ and 4.20 (each $1 \mathrm{H}$, $\left.\mathrm{m}, \mathrm{H}_{2}-1\right), 0.86$ and 1.27 (each $\left.1 \mathrm{H}, \mathrm{m}, \mathrm{H}_{2}-2\right), 1.51(1 \mathrm{H}, \mathrm{m}, \mathrm{H}-3), 1.08$ and 1.54 (each 1H, m, $\left.\mathrm{H}_{2}-4\right), 3.97(1 \mathrm{H}, \mathrm{m}, \mathrm{H}-5), 5.10(1 \mathrm{H}, \mathrm{m}, \mathrm{H}-6), 1.69(3 \mathrm{H}, \mathrm{s}$, $\left.\mathrm{H}_{3}-8\right), 1.64\left(3 \mathrm{H}, \mathrm{s}, \mathrm{H}_{3}-9\right), 3.51$ and 4.01 (each $\left.1 \mathrm{H}, \mathrm{H}_{2}-10\right), 1.23(9 \mathrm{H}, \mathrm{s}, t-\mathrm{Bu})$ and $0.046\left(6 \mathrm{H}, \mathrm{s}, \mathrm{CH}_{3} \times 2\right)$.

Compound 2: White amorphous solid, $[\alpha]_{\mathrm{D}}^{24}-0.79^{\circ}(c=2.0, \mathrm{MeOH})$; HR-EI-MS, $m / z$ : $182.0950\left(\mathrm{M}^{+}\right)\left(\right.$Calcd for $\left.\mathrm{C}_{10} \mathrm{H}_{14} \mathrm{O}_{3} ; 182.0943\right) ;{ }^{1} \mathrm{H}-\mathrm{NMR}$ data in $\mathrm{CDCl}_{3}: \delta 1.72(3 \mathrm{H}, \mathrm{s}, \mathrm{H}-9), 1.75(3 \mathrm{H}, \mathrm{s}, \mathrm{H}-8), 2.63$ and 3.06 (each $1 \mathrm{H}, \mathrm{m}, \mathrm{H}-4), 4.56$ (2H, m, H-1), 5.20 (1H, m, H-5), 5.21 (1H, m, H-6), 6.37 $(1 \mathrm{H}, \mathrm{m}, \mathrm{H}-2) ;{ }^{13} \mathrm{C}-\mathrm{NMR}$ data in $\mathrm{CDCl}_{3}: \delta 18.3(\mathrm{C}-9), 25.7(\mathrm{C}-8), 36.0(\mathrm{C}-4)$ 58.9 (C-1), 75.5 (C-5), 122.8 (C-6), 127.4 (C-3), 140.4 (C-7), 141.5 (C-2), $170.6(\mathrm{C}-10)$.

Acute Toxicity Test for Compound 1 Ten mice per group of each sex weighing $18-22 \mathrm{~g}$ were used. Compound 1 suspended in water was orally administered at the dose of $500-2500 \mathrm{mg} / \mathrm{kg}$. Toxic sighs and mortality were monitored up to day 14 when the test was terminated. $\mathrm{LD}_{50}$ value was calculated by the Litchfield-Wilcoxon method. All procedures involving animal studies were conducted in accordance with the Guidelines for Animal Experiments by New Drug Development Research Center, Inc., and SunTen Phytotech Co., Ltd.

Effect of Compound 1 on the Body Weight of Mice Reared with HighFat Diet Six week-old ddY male SPF mice weighing $25-30 \mathrm{~g}$ were purchased from Japan SLC (Hamamatsu). The animals were housed at $22 \pm 3{ }^{\circ} \mathrm{C}$ subjected to a $12 \mathrm{~h}$ light-dark cycle and $50 \pm 20 \%$ relative humidity with food and water available ad libitum. The mice were kept for 1 week before the experiment. Thereafter, the obesity mice model was induced by feeding a high fat diets (lard 40\%, corn starch 10\%, granulated sugar 9\%, mineral mix $4 \%$, vitamin mix $1 \%$, casein $29 \%$, cellulose $5 \%$, lactose $2 \%$, Nosan Co. Yokohama, Day 0). For the treated group $(n=5)$ with compound $\mathbf{1}$, the compound was suspended in water with the concentration prepared at the dose of $250 \mathrm{mg} / \mathrm{kg} / \mathrm{d}(2.5 \mathrm{mg} / \mathrm{ml}$, mice weight $20 \mathrm{~g} ; 2.9 \mathrm{mg} / \mathrm{ml}, 30 \mathrm{~g} ; 3.3 \mathrm{mg} / \mathrm{ml}$, $40 \mathrm{~g}$ ), and administrated as drinking water freely from day 0 to 42 . In control group, water was administered instead of compound $\mathbf{1}$. The body weight of the mice was measured at a frequency of once a week during the feeding period with the high fat diet. On day 42 , mice were anesthetized with intraperitoneal injection of pentobarbital $(50 \mathrm{mg} / \mathrm{kg})$, and whole blood was taken from the inferior vena cava with a sterile syringe anticoagulated with heparin lithium. Immediately after the collection of blood samples, the mice were exsanguinated and necropsied, and the liver, fat around kidney, posterior abdominal wall and epididymis were weighted. The plasma was obtained by centrifugation $(1870 \times \boldsymbol{g}$ for $10 \mathrm{~min})$ and stored at $-80^{\circ} \mathrm{C}$ until use. The plasma clinical chemistry was analyzed using a Hitachi 7070 Automatic Serum Analyzer (Hitachi Ltd., Tokyo). The concentrations of TC, TG and BG level were measured. The reagents used for the assays of TC, TG, and $\mathrm{BG}$ were purchased from Wako.

Statistical Analysis Data are shown as the mean \pm standard error (S.E.), and $p<0.05$ statistically analysed by Student's $t$-test was considered as significant.

Acknowledgements We thank Professor Wang Tian Zhi of West China School of Pharmacy, Sichuan University for identification of the plant.

\section{References}

1) Tao T., Bai C., Wang T., Du L., Huaxi Yaoxue Zazhi, 19, 178-179 (2004).

2) Zhang C. Z., Li C., Feng S. L., Zhao C. L., Wang W. H., Acta Pharm. Sin., 28, 798-800 (1993).

3) Liu X., Yang P., Pan X., Mianyixue Zazhi, 12, 237-240 (1996).

4) Wang X., Yang B., Chin. J. Chin. Mater. Med., 20, 746-748 (1995).

5) Takemura M., Nishida R., Mori N., Kuwahara Y., Phytochemistry, 61, $135-140$ (2002).

6) Ohtani I., Kusumi T., Kashman Y., Kakisawa H., J. Am. Chem. Soc., 113, 4092-4096 (1991).

7) Sowers J. R., Am. J. Med., 115, 37S-41S (2003).

8) Paulson D. J., Tahiliani A. G., Life Sci., 51, 1557-1569 (1992).

9) Aipert M. A., Hashimi M. W., Am. J. Med. Sci., 306, 117-123 (1993).

10) Kasper E. K., Hruban R. H., Baughman K. L., Am. J. Cardiol., 70, 921-924 (1992).

11) Kenchaiah S., Evans J. C., Levy D., Wilson P. W., Benjamin E. J., Larson M. G., Kannel W. B., Vasan R. S., N. Engl. J. Med., 347, 305-313 (2002).

12) Bray G. A., Ryan D. H., Endocrine, 13, 167-186 (2000).

13) Pi-Sunyer F. X., Ann. Intern. Med., 119, 665-670 (1993). 